\title{
The Transformations of Retail Trade Formats in Europe at the Beginning of the 21 st Century
}

\author{
Marek Drzazga \\ The University of Economics in Katowice, Katowice, Poland
}

\begin{abstract}
The paper aims at identifying the transformations in trade influenced by the main macroeconomic forces of trade companies in European countries in the 21 st century. The author surveys the specialist literature dealing with marketing and trade. On the basis of the research carried out, it has been established that the development of new retail formats (e.g. convenience shops, e-commerce), which was influenced by the transformations in the macroeconomic environment of companies, was observed. At the same time, retail formats of hybrid character (e.g. discount convenience shops) have appeared and old well-known ones like department stores, supermarkets, or discount shops have strengthened their market position. The knowledge about the issues presented in the following paper has practical implications and can be helpful for managers of trade companies.
\end{abstract}

Keywords: macroeconomic environment, retailing, retail format

\section{Introduction}

At the beginning of the 21 st century, the development of various retail formats resulting from the on-going changes in the environment of trade companies was observed (Kraft \& Mantrala, 2006). E-commerce was developing dynamically, as well as convenience shops, and there also appeared trade formats of hybrid character (discount convenience shops). In the period in question, well-known trade formats such as department stores, supermarkets, and discount shops strengthened their market position. The understanding and finding of the roots of the on-going changes in retail formats call for answers to the following questions:

- What main macroeconomic forces of retail trade companies determined the transformations of trade and influenced its evolution at the beginning of the 21 st century?

- What transformations of retail formats took place in retail trade in Europe at the beginning of the 21 st century?

The present paper aims at presenting the most important transformations of retail formats that were influenced by the main macroeconomic forces of trade companies in European countries. Retail trade companies and their evolution at the beginning of the 21 st century constitute the subject of the present paper. The on-going analysis concerns the first decade and the beginning of the second decade of the 21 st century. The analysis carried out here concerns the qualitative changes in the European retail trade, especially in highly

\footnotetext{
Marek Drzazga, assistant professor, Department of Market Policy and Marketing Management, The University of Economics in Katowice, Poland.

Correspondence concerning this article should be addressed to Marek Drzazga, ul.1 Maja 50, 40-287 Katowice, Poland.
} 
developed European countries. The paper makes use of the analysis of the specialist literature concerning marketing and trade, as well as the author's own research dealing with retail trade.

\section{The Main Forces in Trade Companies' Environment at the Beginning of the 21st Century as the Source of the Transformation of Retail Formats}

The transformations that take place in the environment of companies are the cause of, among others, a complete or partial loss of market importance of particular retail formats which are losing market share or which are supplemented and/or replaced by new ones. At the same time, the changes in the environment are the source of other essential transformations that take place in trade.

There were several main forces (Figure 1), stemming from the macroeconomic environment of retail trade companies, that influenced the development and transformations in trade in the first and at the beginning of the second decade of the 21 st century.

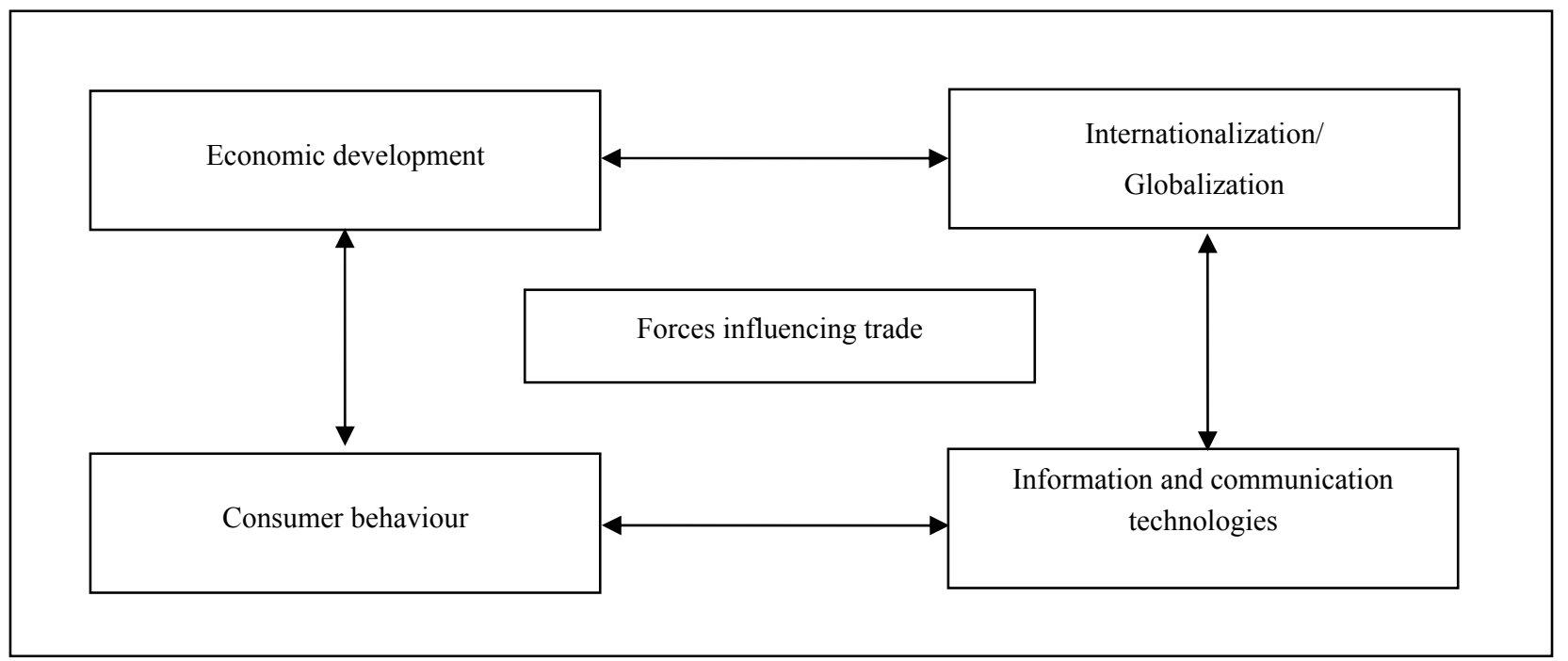

Figure 1. Main forces influencing trade in the 21st century (Rudolph, 2013, p. 8).

Information and communication technologies are, among others, the forces that shape to the greatest extent the contemporary aspect of retail trade in many countries. Quick technological development, especially the development of the Internet, has led to the appearance of new distribution channels and means of communication with the market (so called virtualization of trade) in the past several years. The importance of the Internet and the possibilities of employing it in the activities of trade companies are proved by the increase in the proportions of households in the European Union that have access to the Internet. The rate increased from $41 \%$ in 2004 to $70 \%$ in 2010, and then to $81 \%$ in 2014 (Eurostat, 2015). The above mentioned changes were accompanied by a very intensive development of e-commerce.

Another important force that influenced retail trade at the beginning of the 21 st century is the change in customer behaviour. Sociodemographic changes as well as changing customers' purchasing habits cause the increase of demands placed on trade companies forcing them to constantly modify their trade offer. Such factors as the ageing population in particular countries, the increase in the number of single person households and growing popularization of the Internet have significant impact on changing customer behaviour. A new type of a customer, "a customer of many options", has appeared and become dominant on the markets in many 
highly developed countries. These customers may be characterized as being conscious in their choices and able to play many roles in their lives. Entering the market they stop to live up to established principles. They regard everything as relevant and continually try various solutions. There can be enumerated several basic features of market behaviour of this new type of customers, among others focusing on strong experiencing pleasure, eagerness to take part in various events, high activity, striving for convenience, and possessing the so called brand products, sensitivity to ecology and high price sensitivity (Drzazga, 2012).

Contemporary customers have become more unpredictable in their purchasing behaviour, which is very often contradictory. The above mentioned features of purchasing behaviour may be supplemented also by features like focusing on ecology, homogenization of culture, heterogenization, individualization, deconsumption, virtualization, and presumption (Bywalec, 2010). In the postmodernist society of the period under analysis here, the changes in life styles, consumption patterns, and fashion trends are getting faster and faster (Mróz, 2009).

The internationalization of trade may also be regarded as the force that had a very strong influence on the development of retail trade (at the beginning of the 21 st century in Europe). Retail sales' stagnation led trade companies, especially in highly developed countries, to economic expansion into foreign markets. The process of market liberalization under European integration and/or international agreements has/have accelerated the above mentioned process (Rudolph, 2013).

The beginning of the 21 st century is the time when quickly spreading globalization in world trade can be observed. Many trade companies operating on an international scale appeared. In the first decade and at the beginning of the second decade of the 21st century, European trade companies belonging to the German group Metro (Metro Gruppe), French Carrefour, British Tesco, American Walmart, and, to a lesser extent, companies from Asia (mainly from Japan) and Australia demonstrated great involvement in world markets. Retail trade in many countries has lost its local character, examples of which are Central, Southern, and Eastern European countries.

The economic situation at the beginning of the 21 st century, especially the financial and economic crisis of the end of the first decade, affected international retail trade as well. When the economic situation is stable, the above mentioned macroenvironment force has a limited effect on the development of trade. But at the time of economic recession, this force plays a very important role (discount shops become more important, since customers show a stronger tendency to save money).

The above mentioned main forces of a company's environment forced trade companies to analyse in great detail all the changes that have been taking place on markets, as well as to quickly react to these changes, which is reflected in, among others, the evolution of retail formats.

\section{Transformations and Development of New Retail Formats at the Beginning of the 21st Century}

The issues connected with retail formats constitute a very important area of research, especially in the theory of trade and marketing ${ }^{1}$.

In view of the marketing theory, retail formats come in different shapes and sizes depending on their market competence and the products they offer. A retail format reflects market possibilities of a trade company,

\footnotetext{
1 This is reflected in the specialist literature, among others, in some conceptions of trade formats development, i.e., the natural selection concept, the wheel of retailing concept, the retail accordion concept, and the concept of retail life cycles, which account for system changes in retailing.
} 
including marketing mix instruments. In a broad perspective, while discussing various types of retail formats, a lot of multidimensional elements of a company's policy are taken into consideration. However, when a narrow perspective is adopted, the elements that shape a company's image are taken into consideration (Drzazga, 2012).

A retail format should not be identified with a trade company. A trade company is a selected organizational unit which specializes in the interchange of goods and money, and which may possess one or several types of retail formats (Sławińska, 2008; Sławińska \& Urbanowska-Sojkin, 1997).

Various types of retail formats may be singled out taking into consideration the following elements: organizational and legal form, the degree of links with other companies in the distribution channel, the size of a company, the type of product lines, business line, relative prices that are charged, the organization of sales and services, the amount of service offered, sales areas, location and neighborhood, and owned subsidiaries of a company (Haller, 1997; Hudetz \& Kaapke, 2009; Adamowicz, 2015). To provide an example of the issue at hand here, the classification of retail format types based on the criterion of location will follow (Figure 2).

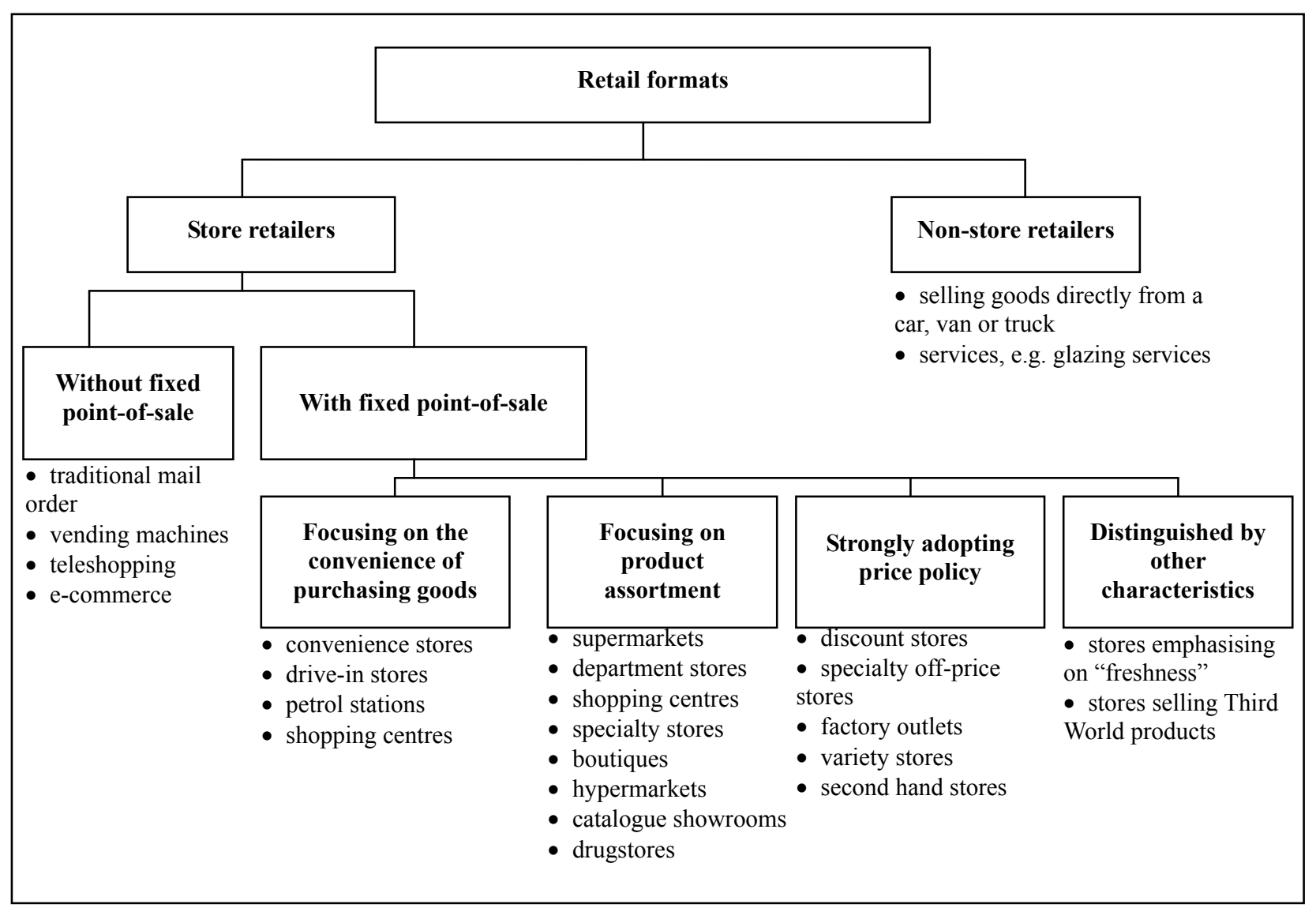

Figure 2. Types of retail formats (Südmeyer, 2003, p. 17).

In this classification, two basic types of retail formats are distinguished, i.e. store retailers and non-store retailers. From among store retailers, one can distinguish those that possess fixed point-of-sale locations, and a number of retail formats that do not possess fixed sales areas, e.g., mail order sales, vending machines designed to retail merchandise, teleshopping, and e-commerce. This classification reflects the changes in retail trade that have been taking place in recent years. 
At the beginning of the 21st century in Europe, especially in highly developed countries, the development of new forms of retailing, especially e-commerce, and convenience shops could be observed. At the same time, there also appeared trade formats of hybrid character (discount convenience shops) and well-known formats of trade such as department stores, supermarkets, and discount shops strengthened their market position (Drzazga, 2012).

But it was the exceptionally rapid development of commerce in the Internet that revolutionized trade in many highly developed countries in the first decade of the 21 st century. Nowadays, the Internet is used to conduct e-business and e-commerce (which constitutes a part of e-business).

Taking into consideration the value and amount of transactions carried out at the beginning of the 21 st century, the key role was played by those transactions that were carried out among economic operators, not the ones carried out between economic operators and individual customers. Nevertheless, the role and importance of the Internet in retailing were increasing.

The development of e-commerce based on the Internet access took place in the first decade of the 21 st century. Later, at the beginning of the second decade, mobile Internet was gaining importance. The activity of companies which is based on mobile Internet is known as m-business, and retailing is known as m-commerce.

Nowadays, the Internet is regarded by trade companies as not only an additional element in sales channel, but also as an integral part of the whole sales system. What happens now is that the process of blending of two worlds of trade, the traditional one, and the electronic one, is taking place. At the beginning of the 21 st century, retail trade is carried out by trade companies with the use of many channels (including the Internet—stationary and mobile), which is reflected in the conception of multichannel trade. Retail trade companies more and more often combine e-commerce and stationary trade. The German trade company-Globetrotter, for many years selling outdoor products (among others, sports products), serves as a good example because it offers its customers, apart from stationary retail outlets, mail order, and catalogue sales in the traditional (paper) and electronic form, as well as an on-line shop and teleshopping (Morschett, 2010).

Convenience shops also underwent a rapid development in the first decade of the 21 st century. These shops offer their customers the most convenient shopping experience, thanks to, Inter Alia, a transparent display of goods, a limited line of high-turnover convenience products, and the shortening of the waiting time at the counter. Convenience shops have been created also by those trade companies that already possess traditional types of retail formats. For example, in France, the Carrefour has created convenience shops - Carrefour City and Carrefour Contact. Spar Express and Billa Stop \& Shop are similar shops in Austria. In Great Britain, Tesco Express, and in Switzerland Coop Pronto and Migrolino are similar types of retail formats (Drzazga, 2012).

At the beginning of the 21 st century, new trade formats of hybrid character started to appear. These new formats are based on the development strategy known as "cross-over", which was borrowed from automotive industry. What is characteristic of the strategy is that it combines the key elements that are typical of various kinds of shops thanks to which they were successful on the market. Lidl-Express, which is a combination of a typical German discount shop with the elements characteristic of British convenience shop may serve as a good example here. The sales area of this shop was half the size of a typical Lidl discount shop and was focused on a big number of customers. The shop sold products typical of British convenience shops, but the prices were like those in discount shops. A significant element of this shop format was that it had its own bakery and a coffee bar selling attractively priced coffee (Queck, 2008). Another example of a hybrid shop format constitutes large 
discount supermarkets such, for instance, as Kaufland shops which have appeared in Germany in the past several years. These shops combine characteristic features of a discount shop (e.g. their way goods are displayed, price policy) and a wide variety of product lines typical of large supermarkets (Hanke, 2009).

It would also be worth mentioning that at the beginning of the 21 st century, traditional trade formats, especially supermarkets, department stores, and shopping centers, in many highly developed European countries underwent interesting transformations. These transformations are the result of the implementation of several new conceptions connected with the functioning of these shops. For example, traditional supermarkets must fulfill the needs of contemporary consumers who, e.g., strive to take active part in events, to feel well, to stay healthy, etc. Modern customers pay more attention to the display of goods, the arrangement of sales areas, as well as selling of high quality products. In order to create individual profile of supermarkets, counters with personal sale are more and more often introduced.

Moreover, department stores strive to make them more attractive by the implementation of new marketing conceptions. They attempt to create a unique atmosphere in the shop, thus making their customers feel better and stay longer in the shop, which in consequence, influences the increase in the sales of products (Zentes, Morschett, \& Schramm-Klein, 2007).

The transformations in the trade formats presented above were the ones that are the most conspicuous in retail trade, especially in highly developed European countries, at the beginning of the 21 st century.

\section{Conclusions}

The beginning of the 21 st century is the time when the most important transformations of various trade formats took place. E-commerce developed dynamically, and at the beginning of the second decade of the 21 st century, it became part of everyday life in the majority of highly developed countries all over the world. At the time in question here, e-commerce and traditional trade blended creating the so called multichannel trade.

At the same time the transformations taking place in the environment of trade companies, caused to a large extent by the changes in customer buying behaviour, set free a rapid development of convenience shops and shops of hybrid character which are a peculiar blend of various trade formats.

At that time also traditional shop formats, such as supermarkets, superstores, and department stores were subjected to change. In the face of a strong competition on the market, these shop formats were forced to implement many conceptions and solutions to stay attractive in the eyes of their customers.

Finally, it would be worth mentioning that a modern customer is in the possession of the access to unprecedented choice of the possibilities to supply her/his household.

\section{References}

Adamowicz, M. (2015). Przekształcenia w sektorze handlu detalicznego i strategiach przedsiębiorstw na rynkach towarów konsumpcyjnych w Polsce. Handel Wewnętrzny, 5, 358.

Bywalec, C. (2010). Konsumpcja a rozwój gospodarczy i społeczny. Warszawa: C.H. Beck.

Drzazga, M. (2012). Komunikacja marketingowa przedsiębiorstw handlu detalicznego z rynkiem. Katowice: Wydawnictwo Uniwersytetu Ekonomicznego w Katowicach.

Eurostat. (2015). Internet-Zugangsdichte-Haushalte. Prozentsatz der Privathaushalte mit Internet-Zugang. Einschließlich sämtlicher Formen der Internetnutzung. Bevölkerung im Alter zwischen 16 und 74 . Retrieved from http: //ec.europa.eu/eurostat/tgm/table.do?tab $=$ table\&init $=1 \&$ language $=$ de\&pcode $=$ tin00134\&plugin $=1$

Haller, S. (1997). Handels-Marketing. Ludwigshafen (Rhein): Friedrich Kiel Verlag.

Hanke, G. (2009). Mitten-im-Leben-Konzept. Lebensmittelzeitung, 44. 
Hudetz, K., \& Kaapke, A. (2009). Lexikon Handelsmanagement. Controlling_Führung-Marketing. Ludwigshafen (Rhein): Deutscher Fachverlag.

Kraft, M., \& Mantrala, M. (2006). Retailing in the 21st century: Current and future trends. Berlin-Heidelberg: Springer.

Morschett, D. (2010). Wachstum durch innovative Betriebstypenpolitik. Aachen: Shaker Verlag.

Mróz, B. (2009). Consumo ergo sum? Rola konsumpcjonizmu we współczesnych społeczeństwach. In B. Mróz (Ed.), Oblicza konsumpcjonizmu. Warszawa: Szkoła Główna Handlowa.

Queck, M. (2008). Caffe lidl. Lebensmittel Zeitung, 34.

Rudolph, T. (2013). Modernes handelsmanagement. Stuttgart: Schäfer Verlag.

Sławińska, M. (ed.) (2008). Kompendium wiedzy handlu. Warszawa: Wydawnictwo Naukowe PWN.

Sławińska, M., \& Urbanowska-Sojkin, E. (1997). Zarzq̨dzanie marketingowe przedsiębiorstwem handlowym. Poznań: Akademia Ekonomiczna.

Südmeyer, V. (2003). Wettbewerbsvorteile durch strategisches Betriebsformenmanagement. Frankfurt am Main: Peter Lang-Europäischer Verlag der Wissenschaften.

Zentes, J., Morschett, D. H., \& Schramm-Klein, H. (2007). Strategic retail management-Text and international cases. Wiesbaden: Gabler Verlag. 